Г. В. Громов, А. В. Носовський, Н. П. Валігун, І. І. Воробей

Державне підприємство «Державний науково-технічний центр з ядерної та радіаційної безпеки», м. Київ, Україна

\title{
Результати
}

\section{науково-технічної діяльності ДНТЦ ЯРБ за 2011 рік}

Представлено основні результати науково-технічної діяльності Державного підприємства «Державний науково-технічний центр з ядерної та радіаційної безпеки» у 2011 р. з розвитку системи нормативного регулювання ядерної та радіаційної безпеки, експертно-аналітичної діяльності, науково-технічної підтримки наглядової функції державного регулювання, наукових та аналітичних досліджень з обґрунтування регулюючих рішень, а також науково-інформаційної та міжнародної діяльності підприємства. Висвітлено участь ДНТЦ ЯРБ як організації науково-технічної підтримки державного регулювання ядерної та радіаційної безпеки у заходах з поглибленої переоцінки безпеки енергоблоків АЕС України, необхідність реалізації яких виникла у зв'язку з подіями на AEC «Фукусіма-1» в Японії.

Ключові слова: Держатомрегулювання України, АEC, ДНТЦ ЯРБ, ЯРБ, технічна оцінка, переоцінка безпеки, стрес-тест.

\section{Г. В. Громов, А. В. Носовский, Н. П. Валигун, И. И. Воробей}

Результаты научно-технической деятельности ГНТЦ ЯРБ за 2011 год

Представлены основные результаты научно-технической деятельности Государственного предприятия «Государственный научно-технический центр по ядерной и радиационной безопасности» в 2011 г. по развитию системы нормативного регулирования ядерной и радиационной безопасности, экспертно-аналитической деятельности, научнотехнической поддержки надзорной функции государственного регулирования, научных и аналитических исследований по обоснованию регулирующих решений, а также научно-информационной и международной деятельности предприятия. Освещено участие ГНТЦ ЯРБ как организации научно-технической поддержки государственного регулирования ядерной и радиационной безопасности в мероприятиях по углубленной переоценке безопасности энергоблоков АЭС Украины, необходимость реализации которых возникла в связи с событиями на АЭС «Фукусима-1» в Японии.

Ключевые слова: Госатомрегулирования Украины, АЭС, ГНТЦ ЯРБ, ЯРБ, техническая оценка, переоценка безопасности, стресс-тест.

(C) Г. В. Громов, А. В. Носовський, Н. П. Валігун, І. І. Воробей, 2012

Д ержавне підприємство «Державний науковотехнічний центр з ядерної та радіаційної безпеки» (ДНТЦ ЯРБ) створено в лютому 1992 р. відповідно до постанови Кабінету Міністрів України від 03.02.1992 р. № 52 з метою науковотехнічної, експертної та інформаційно-аналітичної підтримки діяльності Держатомрегулювання України, спрямованої на захист населення та довкілля від радіаційного впливу техногенного походження [1].

І̇з 2008 р. ДНТЦ ЯРБ має статус подвійного підпорядкування - Держатомрегулюванню України та Національній академії наук України (далі - НАН України). Держатомрегулювання України здійснює щодо ДНТЦ ЯРБ передбачені законодавством функції з управління державним майном, яке закріплене за ДНТЦ ЯРБ на правах господарського відання, НАН України - науково-методичне керівництво діяльністю ДНТЦ ЯРБ. За науковою спрямованістю діяльності ДНТЦ ЯРБ входить до складу Відділення ядерної фізики та енергетики НАН України.

У 2011 р. ДНТЦ ЯРБ здійснював наукову, аналітичну, експертну підтримку визначених законодавством функцій та завдань органу державного регулювання ядерної та радіаційної безпеки. Планування основної діяльності й реалізація передбачених заходів відповідали «Стратегії розвитку системи регулювання ядерної та радіаційної безпеки в Україні на 2008-2012 роки», «Плану заходів щодо реалізації Енергетичної стратегії України на період до 2030 року», «Програмі розвитку Державного підприємства “Державний науково-технічний центр з ядерної та радіаційної безпеки” на 2010-2012 рр.», планам діяльності регулюючого органу на 2011 р., а також рішенням колегії та дорученням керівництва Держатомрегулювання України.

У 2011 р. безпека ядерної галузі стала однією з актуальних тем, шо схвилювала світову спільноту та органи влади подіями на АEC «Фукусіма-1». Трагедія на японській АЕC показала, що потрібно приділяти більше уваги питанням проектної безпеки, можливостям атомних енергоблоків протистояти незвичайним природним катаклізмам, водневій безпеці i, безумовно, питанням аварійного реагування.

17 березня 2011 р. в «Заяві про наміри Держатомрегулювання України, у зв'язку з подіями на АЕС “Фукусіма-1"» наголошено на необхідності вивчення уроків аварії, прийняття в найкоротші терміни рішення про впровадження додаткових заходів щодо підвищення безпеки енергоблоків АЕС України в умовах проектних і запроектних аварій. У розвиток реалізації таких намірів, ДНТЦ ЯРБ було підготовлено аналітичні матеріали 3 проведення стрес-тестів, які використані Держатомрегулюванням України у розробці «Плану дій з виконання цільової позачергової перевірки й подальшого підвищення безпеки АЕС України з урахуванням подій на “Фукусіма-1"».

На засіданні колегії Держатомрегулювання України від 19.05.11 p. № 2 узгоджено «План дій з виконання цільової позачергової оцінки стану безпеки та подальшого підвищення безпеки енергоблоків АЕС України з урахуванням подій на АЕС “Фукусіма-1”», яким передбачено впровадження як короткострокових, так і довгострокових заходів [2].

ДНТЦ ЯРБ протягом звітного періоду брав активну участь у реалізації короткострокових заходів стосовно:

виконання цільової переоцінки безпеки енергоблоків діючих АЕС та Державного спеціалізованого підприємства «Чорнобильська АЕС» (далі - ДСП «ЧАЕС») (стрес-тести); перегляду та доповнення «Комплексної (зведеної) програми підвищення безпеки енергоблоків АЕС України»;

проведення аналізу нормативно-правової бази ядерної та радіаційної безпеки (ЯРБ) та розробки пропозицій 
щодо їі вдосконалення й підвищення вимог з безпеки для діючих і нових енергоблоків АЕС.

Науково-технічна підтримка вирішення завдань регулювання ЯРБ забезпечувалася в 2011 р. за такими напрямами: безпека ядерних установок (далі - ЯУ), запланованих до будівництва;

підвищення безпеки та модернізація діючих енергоблоків АEC;

обгрунтування безпеки та контроль поточного стану безпеки діючих енергоблоків АЕС; продовження терміну експлуатації АЕC;

фізичний захист ЯУ, ядерних матеріалів, радіоактивних відходів (далі - РАВ) та джерел іонізуючого випромінювання (далі - Дї);

зняття з експлуатації АЕС;

перетворення об'єкта «Укриття» (далі - ОУ) на екологічно безпечну систему;

поводження з відпрацьованим ядерним паливом (далі - ВЯП);

поводження з РАВ;

впровадження нових видів ядерного палива;

радіаційний захист при використанні ДїВ у медицині, науці та промисловості.

Міжнародна діяльність ДНТЦ ЯРБ у 2011 р. мала спрямування на підвищення якості технічного оцінювання безпеки. Значна частина такого оцінювіання виконувалася в рамках довгострокових програм співробітництва та міжнародної допомоги у взаємодії з експертами країн ЄС та США і охоплювала практично всі проекти, що впроваджуються на українських об'єктах за сприяння міжнародної спільноти. Цього року суттєво поширилася участь ДНТЦ ЯРБ в діяльності таких міжнародних організацій, як ETSON та МАГАТЕ. Крім того, починаючи з 2011 р., ДНТЦ ЯРБ є співорганізатором щорічного форуму європейських організації технічної підтримки EUROSAFE.

За оцінками Національного бізнес-рейтингу серед підприємств державної форми власності, ДНТЦ ЯРБ у 2011 р. посіло перше місце в Україні за основним видом діяльності «Дослідження і розробки в галузі технічних наук» та нагороджено почесним званням і медаллю «Державне підприємство року».

Престижність наукової праці в ДНТЦ ЯРБ зростає завдяки поширенню результатів наукових досліджень (розробок) працівників шляхом:

публікації результатів наукових досліджень спеціалістів ДНТЦ ЯРБ у спеціалізованому журналі «Ядерна та радіаційна безпека» й інших наукових періодичних виданнях;

видання монографій;

участі в роботі наукових і громадських організацій, спеціалізованих вчених та науково-технічних рад організацій ядерної галузі;

співпраці з національними та міжнародними науковими організаціями й товариствами.

Метою статті є оприлюднення результатів науково-технічної діяльності ДНТЦ ЯРБ за 2011 р., представлених у рамках щорічного звіту за основними напрямами діяльності [3].

Основні результати науково-технічної діяльності. Науковотехнічна діяльність ДНТЦ ЯРБ відповідно до Статуту підприємства здійснюється за завданням Держатомрегулювання. Основними видами робіт ДНТЦ ЯРБ є:

розробка проектів норм, правил і стандартів у сфері ядерної та радіаційної безпеки; науковий і аналітичний супровід процесів регулюючої діяльності, пов'язаної з використанням ядерної енергії та радіаційних технологій;

експертна підтримка й оцінка поточного стану ЯРБ ЯУ і радіаційних технологій, оцінка ризику від їх застосування.

Усі напрями науково-технічної діяльності ДНТЦ ЯРБ супроводжуються вивченням й аналізом передового міжнародного досвіду регулювання та забезпечення безпеки у сфері використання ядерної енергії.

У рамках реалізації «Плану дій з виконання цільової позачергової перевірки та подальшого підвищення безпеки AЕС України з урахуванням подій на АЕС “Фукусіма-1"”, фахівцями ДНТЦ ЯРБ протягом 2011 р. організовано постійний моніторинг та аналіз даних, що надходять з різних джерел інформації: МАГАТЕ, ETSON тощо; підготовлено та надано Держатомрегулюванню України пропозиції щодо уточнення зведеної комплексної програми підвищення безпеки; пропозиції до Перспективного плану виконання науково-дослідних та дослідно-конструкторських робіт ДНТЦ ЯРБ; пропозиції з коригування нормативної бази ЯРБ; взято участь у реалізації невідкладних заходів з удосконалення нормативно-правової бази; розроблено рекомендації щодо структури й змісту звітів з цільової переоцінки безпеки (на підставі технічних умов ENSREG/ WENRA на проведення стрес-тестів); взято участь у заходах як національного, так і міжнародного рівня з розгляду причин і наслідків аварії на АЕС «Фукусіма-1» та нових актуальних завдань, що виникли у зв’язку з цією подією; завершено технічне оцінювання результатів виконання цільової позачергової оцінки стану безпеки діючих енергоблоків АЕС, сухого сховища відпрацьованого ядерного палива Запорізької АЕС (далі - ССВЯП) та ДСП «ЧАЕС»; на підставі схвалених колегією Держатомрегулювання України висновків державної експертизи взято участь у підготовці матеріалів до Національного звіту з цільової переоцінки безпеки АЕС України.

Протягом звітного періоду ДНТЦ ЯРБ брав участь у подальшому розвитку нормативно-правової бази з ЯРБ; здійснював науковий та аналітичний супровід процесів регулюючої діяльності, пов'язаної з використанням ядерної енергії та радіаційних технологій; надавав експертну підтримку та здійснював оцінку поточного стану ЯРБ ЯУ та радіаційних технологій, оцінку ризику від їх застосування (виконано 446 експертиз, 82 експертні оцінки).

Результати наукових досліджень, виконаних фахівцями ДНТЦ ЯРБ, висвітлюються на конференціях, форумах, семінарах як національного, так і міжнародного рівня, публікуються в наукових виданнях. Протягом 2011 р. на зазначених вище заходах фахівцями ДНТЦ ЯРБ представлено 33 доповіді.

Фахівці ДНТЦ ЯРБ є членами дорадчо-консультативних органів Держатомрегулювання та Мінпаливенерго, Технічного комітету ТK-45, Міжвідомчої робочої групи 3 координації діяльності регулюючих органів під час видачі ліцензій на виконання робіт на ОУ та зі зняття ЧАЕС з експлуатації, Технічного комітету стандартизації «Атомна енергія» ТК-79, Міжвідомчої експертної робочої групи з питань протидії загрозам розповсюдження зброї та матеріалів масового знищення, а також Українського ядерного товариства.

На регулярній основі керівництво ДНТЦ ЯРБ бере участь у роботі засідань Ради головних інженерів АЕС (далі - РГїC), організатором яких виступає Державне підприємство «Національна атомна енергогенеруюча компанія 
“Енергоатом” (далі - ДП НАЕК «Енергоатом»). Основними питаннями засідань РГІІС є обговорення поточної інформації про порушення в роботі АЕС. У 2011 р. відбулося чотири таких засідання.

Для колегіального вирішення питань за напрямами основної діяльності в ДНТЦ ЯРБ на постійній основі працюють Експертна та Науково-технічна ради, метою роботи яких є зростання ефективності діяльності підприємства, розвиток перспективних напрямів досліджень, координація роботи наукових підрозділів і підвищення якості науково-технічної продукції. Протягом 2011 р. проведено 10 засідань Науково-технічної ради та понад 40 засідань Експертної ради ДНТЦ ЯРБ.

Розвиток системи нормативного регулювання. ДНТЦ ЯРБ з часів свого заснування брав участь у розробці понад 100 нормативних, рекомендаційних та методичних документів, що регулюють безпеку ЯУ; безпеку джерел Дїв; безпеку перевезень ядерних матеріалів (далі - ЯМ); безпеку поводження з РАВ; безпеку ОУ; фізичний захист.

Протягом звітного періоду, з метою оновлення нормативної бази та напрацювання методичної бази Держатомрегулювання, ДНТЦ ЯРБ брав участь у розробці (перегляді) проектів 14 нормативних документів, якими встановлюються вимоги та рекомендації щодо систем управління безпекою при здійсненні діяльності у сфері використання ядерної енергії та на всіх етапах життєвого циклу ЯУ; забезпечення безпеки підкритичної збірки; оцінки безпеки АEC; безпеки експлуатації обладнання та трубопроводів АЕС; фізичного захисту при проектуванні ЯУ, об’єктів, призначених для поводження з РАВ, та інших ДїВ; цифрових інформаційних та керуючих систем, важливих для безпеки АЕС; локалізуючих систем безпеки енергоблоків АЕС; систем надійного електропостачання, важливих для безпеки АEC; експлуатації систем надійного електропостачання; безпеки дослідницьких реакторів; системи та обладнання майданчиків тимчасового зберігання транспортних пакувальних комплектів з ВЯП на АЕС; протипожежних норм проектування АЕС з водо-водяними енергетичними реакторами.

Відповідно до доручення Держатомрегулювання України, у жовтні 2011 р. фахівцями ДНТЦ ЯРБ виконано аналіз нормативних документів, вимоги яких потребують коригувань у контексті аварійних подій на АЕС «Фукусіма», з метою однозначного виключення їх виникнення на АЕС України. За результатами аналізу визначено основні фактори, які призвели до виникнення на майданчику АЕС «Фукусіма» важкої аварії з довготривалими радіаційними наслідками, виконано аналіз чинної в Україні нормативної бази та сформовано попередній перелік документів, що потребують коригувань, стисло визначено напрями перегляду їх з урахуванням аварійних феноменів, що мали місце на АЕС «Фукусіма».

Результати цих досліджень стали підгрунтям для виконання НДР щодо комплексного аналізу норм, правил та стандартів з ядерної безпеки з урахуванням уроків аварії на АЕС «Фукусіма-1», за результатами якої підготовлено пропозиції щодо внесення відповідних змін.

У грудні 2011 р., на виконання доручення Держатомрегулювання України, в ДНТЦ ЯРБ створено робочу групу з аналізу та удосконалення нормативно-правової бази в сфері ЯРБ, якій доручено: а) проведення комплексного аналізу чинних норм, правил і стандартів з ЯРБ, виходячи з пріоритету забезпечення безпеки людини й довкілля при використанні ядерної енергії, з урахуванням міжнародного досвіду та підходів до регулювання безпеки, а також рекомендацій МАГАТЕ; б) розробка пропозицій шодо вдосконалення нормативної бази з ЯРБ.

Фахівцями ДНТЦ ЯРБ постійно проводяться наукові та аналітичні дослідження з різних напрямів діяльності підприємства на підтримку нормотворчої діяльності регулюючого органу, зокрема в контексті адаптації вітчизняного законодавства до законодавства Європейського Союзу.

У 2011 р. фахівцями ДНТЦ ЯРБ підготовлено понад 20 аналітичних, узагальнюючих, інформаційних матеріалів до документів Держатомрегулювання та провідних організацій галузі; надано 15 пропозицій до проектів розпорядчих документів, розроблених центральними органами виконавчої влади України, та до пріоритетних напрямів діяльності й планів розвитку Держатомрегулювання. Для Технічного комітету зі стандартизації ТК-79 внесено 5 пропозицій щодо пріоритетності розробки та перегляду національних стандартів. Крім того, підготовлено відгуки на проекти 17 нормативних документів, які розроблялися Держатомрегулюванням, іншими центральними органами виконавчої влади, розглянуто 12 документів МАГАТЕ.

Результати експертної діяльності. Експертно-аналітична діяльність ДНТЦ ЯРБ у звітний період спрямовувалася на вирішення пріоритетних завдань Держатомрегулювання та зосереджувалася на технічному оцінюванні безпеки документів за напрямами термогідравлічних процесів; імовірнісного аналізу безпеки; аналізу експлуатаційної безпеки AEC; нейтронно-фізичних розрахунків та фізики реактора; поводження з ВЯП та РАВ; міцності та конструкційної надійності; надійності систем контролю та управління; радіаційного захисту і аналізу дозових навантажень; фізичного захисту ЯУ.

У частині підтримки ліцензійної діяльності Держатомрегулювання України, експертно-аналітична діяльність ДНТЦ ЯРБ базується на регулярному конструктивному діалозі в процесі технічного оцінювання ліцензійних документів. У 2011 р. за участю представників ліцензіатів та регуляторів відбулося понад 30 нарад, на яких обговорювалися невирішені питання безпеки.

Важливим для ДНТЦ ЯРБ цього року стало залучення до поглибленого переоцінювання безпеки енергоблоків АЕC України, необхідність якого виникла у зв'язку з подіями, що сталися у березні 2011 р. в Японії на АЕС «Фукусіма-1».

Фахівцями ДНТЦ ЯРБ були підготовлені аналітичні матеріали з цільового позачергового оцінювання стану безпеки енергоблоків АЕС України (стрес-тести). Аналітичні матеріали використані Держатомрегулюванням України при розробці «Плану дій з виконання цільової позачергової перевірки й подальшого підвищення безпеки АЕС України з урахуванням подій на Фукусіма-1» (далі - План дій), який погоджено 19.05.2011 р. на засіданні колегії Держатомрегулювання України. Підходи до переоцінювання безпеки містять як короткострокові, так і довгострокові заходи.

Короткостроковими заходами Плану дій передбачено, зокрема, перегляд та внесення доповнень до «Комплексної (зведеної) програми підвищення безпеки енергоблоків АЕС України» (далі - КзППБ).

Зміни до КзППБ в частині реалізації Плану дій та визначення пріоритетних заходів, що розроблені ДП НАЕК «Енергоатом», проходили технічну оцінку в ДНТЦ ЯРБ. Експертами було зауважено на необхідності виконання сейсмічного імовірнісного аналізу безпеки з встановленням вищого пріоритету; аналізу ядерної безпеки вузла свіжого палива стосовно зберігання в ньому нових та використовуваних 
на цей час видів палива; доповнення КзППБ вимогами про необхідність врахування міжнародного досвіду з питань водневої вибухобезпечності (зокрема досвіду подій на АЕС «Фукусіма-1»).

Відповідно до Плану дій, вимог Держатомрегулювання України і Європейської групи регулюючих органів з питань ядерної безпеки (ENSREG), ДП НАEK «Енергоатом» виконав цільову переоцінку безпеки відносно зовнішніх екстремальних природних впливів, які можуть призвести до деградації функцій безпеки (стрес-тести).

Звітні матеріали про результати стрес-тестів діючих АЕС України та ДСП «ЧАЕС» проходили технічну оцінку в ДНТЦ ЯРБ.

Цільову переоцінку безпеки для майданчика ДСП «ЧАEC» виконано в рамках окремого дослідження, їі результати розглянуто та схвалено під час засідання колегії Держатомрегулювання України 3 листопада 2011 р. [4].

Результати технічної оцінки стрес-тесту ДСП «ЧАЕС» показали:

стрес-тест ДСП «ЧАЕС» відповідає вимогам до проведення стрес-тестів для європейських AEC (Declaration of ENSREG, Annex 1 «EU "Stress-test" specifications»);

ДСП «ЧАЕС» коректно визначені найнебезпечніші впливи, а саме: землетрус та смерч;

забезпечується відновлення електропостачання та тепловідведення від відпрацьованих тепловидільних збірок (далі - ВТВ3) менше ніж за 8 год за самих несприятливих умов;

підтверджено працездатність системи аварійної готовності та реагування, яка може ефективно застосовуватися в умовах впливів екстремальних природних подій на проммайданчику ДСП «ЧАЕС».

За результатами стрес-тесту ДСП «ЧАЕС» запланувало розробку Плану підвищення безпеки ЯУ ЧАЕС. Стрестест показав доцільність зменшення кількості ЯУ, на яких зберігаються ВТВЗ. ДСП «ЧАЕС» має включити до Плану підвищення безпеки ЯУ ЧАЕС питання, що не були розглянуті у стрес-тесті:

аналіз поведінки ВТВ3, що мають високу температуру, під впливом води;

відновлення працездатності пошкодженого під впливом землетрусу та (або) смерчу обладнання для переміщення ВТВ3 зі СВЯП-1 на інші ЯУ (зокрема прискорення створення нового вагона-контейнера);

аналіз сценарію та наслідків запроектної аварії в умовах впливу смерчу класу F 3.0 (у першу чергу для СВЯП-1);

визначення особливостей аварійного реагування при запроектних аваріях, до яких призводять екстремальні впливи.

Щодо діючих енергоблоків АЕС та ССВЯП Запорізької $A E C$ (далі - ЗАЕС), цільова переоцінка безпеки виконана з урахуванням відмінностей та специфіки майданчиків, а також типів реакторних установок (далі - РУ), які експлуатуються в Україні.

Під час цільового переоцінювання безпеки за потенційне джерело загрози розглядалося ядерне паливо, що знаходиться в активній зоні реактора, басейні витримки, ССВЯП і вузлі зберігання свіжого палива. Цільове переоцінювання безпеки виконано з урахуванням усіх можливих природних впливів або їх комбінації та для всіх експлуатаційних станів енергоблоків (робота на потужності та у стані останову).

За результатами стрес-тестів встановлено:

позачергове переоцінювання безпеки в рамках стрестестів не виявило нових дефіцитів безпеки, а також додат- кових (не врахованих проектом) зовнішніх екстремальних впливів та їх комбінацій, які можуть негативно вплинути на безпеку AEC;

проектні основи, закладені під час будівництва енергоблоків АЕС України, гарантують високу стійкість діючих енергоблоків ВВЕР до зовнішніх екстремальних впливів та їх комбінацій, а також свідчать про наявність запасів безпеки на етапі експлуатації енергоблоків АEC;

протягом експлуатації енергоблоків АЕС реалізовано комплекс заходів з підвищення їхньої безпеки, які, зокрема, підвищують стійкість АЕС до зовнішніх екстремальних впливів і їх можливих наслідків.

Реалізовані заходи з підвищення безпеки грунтуються на рекомендаціях МАГАТЕ (Issues books), результатах розроблених звітів з аналізу безпеки, вітчизняного та міжнародного досвіду експлуатації. В рамках проекту ЄК-України-МАГАТЕ з оцінки проектної безпеки (20082010 рр.) підтверджено відповідність стану безпеки енергоблоків АЕС України сучасним стандартам МАГАТЕ та наголошено на необхідності продовження реалізації заходів щодо сейсмічної кваліфікації обладнання та управління важкими аваріями.

На підставі результатів стрес-тестів виявлено здатність енергоблоків АЕС України протистояти складним комплексним аваріям з накладенням багатьох різноманітних відмов систем і елементів, а також зовнішніх екстремальних впливів. Висока надійність енергоблоків досягається постійним впровадженням заходів з підвищення рівня безпеки АЕC.

У рамках КзППБ продовжується реалізація заходів, спрямованих на подальше підвищення безпеки AEC: проводяться роботи $з$ додаткового сейсмічного дослідження майданчиків, кваліфікації обладнання на сейсмічні впливи, розробки посібників з управління важкими аваріями тощо. Реалізація зазначених заходів збільшить наявні запаси безпеки щодо стійкості енергоблоків АЕС до зовнішніх екстремальних впливів.

За результатами стрес-тестів, ДП НАЕК «Енергоатом» розроблено пропозиції з реалізації додаткових заходів щодо використання мобільних установок для забезпечення можливості відведення залишкового тепла від палива до 72 год у разі повного знеструмлення АЕC та втрати кінцевого поглинача тепла, що дасть змогу підвищити рівень безпеки енергоблоків АЕС України до рівня сучасних міжнародних вимог до нових проектів АЕС покоління III+ (вимоги EUR).

B частині управління важкими аваріями в рамках стрес-тестів виконано розрахункові аналізи та розроблено пропозиції щодо реалізації заходів за основними феноменами важких аварій, які мали місце на АЕС «Фукусіма-1»: воднева небезпека і переопресовування гермооболонки.

За результатами проведеної технічної оцінки ДНТЦ ЯРБ встановлено, що висновки ДП НАЕК «Енергоатом» щодо стійкості енергоблоків АЕС України до зовнішніх екстремальних впливів можна вважати коректними. Разом с тим, ДП НАЕК «Енергоатом» необхідно в стислі терміни реалізувати комплекс заходів з підвищення стійкості до сейсмічних впливів; із забезпечення відведення тепла від ядерного палива при запроектних аваріях із множинними відмовами обладнання; з управління важкими аваріями.

Результати стрес-тестів діючих енергоблоків АЕС та ССВЯП ЗАЕС було обговорено та, в цілому, схвалено під час розширеного засідання колегії Держатомрегулювання України 24-25 листопада 2011 р. [5]. 
На підставі звітів з цільового переоцінювання безпеки Держатомрегулюванням Україні у грудні 2011 р., за участі ДНТЦ ЯРБ, розроблено та надано на розгляд ENSREG Національний звіт з цільового переоцінювання безпеки AEC України. Основні положення Національного звіту України щодо результатів проведення стрес-тестів для АЕС України представлені на відкритому засіданні колегії Держатомрегулювання України 20 грудня 2011 р. Незалежна партнерська перевірка Національного звіту України має бути виконана представниками регулюючих органів країн Євросоюзу до кінця квітня 2012 р.

За результатами позачергового переоцінювання рівня безпеки енергоблоків АЕС та на виконання рішення колегії Держатомрегулювання України від 24-25 листопада 2011 р. ДП НАЕК «Енергоатом» розроблено додатковові заходи з підвищення рівня безпеки та щорічні плани-графіки із зазначенням строків здійснення таких зведених заходів, внесено відповідні зміни до КзППБ. Аналіз внесених доповнень до КзППБ проведено фахівцями ДНТЦ ЯРБ. Держатомрегулюванню України надано коментарі щодо коректності, достатності передбачених заходів, а також прийнятності запропонованих термінів виконання.

7 грудня 2011 р. Кабінет Міністрів України наказом № 1270 затвердив доповнену, з урахуванням результатів стрес-тестів, КзППБ, реалізація якої дасть змогу:

підвищити рівень безпеки енергоблоків АЕС відповідно до міжнародних стандартів;

удосконалити основні критерії ядерної безпеки, визначені нормами та правилами ЯРБ (зниження рівня ймовірності пошкодження активної зони реактора й аварійних викидів радіоактивних речовин), а також зменшити кількість відмов обладнання енергоблоків АЕС та їх позапланових зупинок;

створити необхідні умови для прийняття рішень щодо можливості продовження строків експлуатації енергоблоків АЕС.

Науково-технічна підтримка наглядової функції Держатомрегулювання України є одним з основних напрямів діяльності ДНТЦ ЯРБ і полягає в реалізації пріоритету підвищення ефективності інспекційної діяльності завдяки переходу від перевірок відповідності вимогам норм і правил та їх дотримання до оцінювання поточного стану безпеки на об'єктах, що реалізується: а) вдосконаленням норм та методологічного забезпечення, розробки інспекційних планів; б) участю фахівців ДНТЦ ЯРБ в інспекційних обстеженнях; в) розробкою та впровадженням сучасних методів планування, підготовки, проведення і оцінки результатів інспекційних перевірок.

У 2011 р. на підтримку наглядової функції державного регулювання виконувалось 14 робіт, зосереджених, зокрема, на розвитку методологічних підходів до цільових обстежень (три роботи) і проведенні спільних інспекцій та аналізів отриманих результатів (11 обстежень).

На українських АЕС було введено особливий режим, а також проведено протиаварійні тренування на ЗАЕС та Южно-Українській АЕС (далі - ЮУАЕС). Фахівці ДНТЦ ЯРБ брали участь у цих тренуваннях як спостерігачі.

Для надання методологічної підтримки інспекційним підрозділам Держатомрегулювання України та впровадження єдиного підходу щодо регулюючої оцінки фахівцями ДНТЦ ЯРБ розроблялися:

загальні вимоги до процедури здійснення регулюючого контролю в сфері впровадження керівництв з управління важкими аваріями; керівництво для інспекторів Держатомрегулювання України щодо регулюючої оцінки протиаварійних тренувань Ліцензіата;

удосконалений технічний посібник для другого блока Хмельницької АЕС (далі - ХАЕС) з метою підтримки інспекційної діяльності (в рамках впровадження ризикорієнтованих підходів у інспекційну діяльність).

У рамках підтримки наглядової функції експертами ДНТЦ ЯРБ протягом 2011 р. проведено аналізи:

порушень у роботі AEC;

результатів контролю метала корпусу реактора зсередини енергоблоків 1 та 2 ЗАЕС в період ППР-2011;

звіту з розслідування на енергоблоці 2 ХАЕС стосовно «Достижение ТВСА №A399602031 критерия отказа по удельной активности İ-131 при проведении контроля герметичности оболочек твэл на остановленном реакторе»;

результатів роботи спільної українсько-російської комісії з визначення причин підвищення активності теплоносія першого контуру на енергоблоці 2 ХАЕС під час проведення 6-ї кампанії.

Фахівці ДНТЦ ЯРБ систематично беруть участь у підготовці та проведенні інспекційних перевірок українських AEC, об'єктів, призначених для поводження з РАВ, тощо (зокрема, у 2011 р. - в 12 інспекційних заходах) з метою надання науково-технічної підтримки державним інспекторам Держатомрегулювання України під час оцінки конкретних технічних питань, що пов'язані з безпекою об'єктів перевірки.

ДНТЦ ЯРБ регулярно залучається Держатомрегулюванням України до проведення приймальних випробувань обладнання, призначеного для модернізацій або реконструкції систем та елементів, важливих для безпеки АЕС. У 2011 р. проведено 13 таких випробувань, більшість з яких - на майданчиках науково-виробничих об'єднань «Радій» та «Імпульс».

Для використання в найближчому майбутньому мобільної лабораторії радіаційної розвідки RanidSonni під час інспекційних обстежень радіаційно-ядерних об'єктів потрібно провести атестацію автомобіля та пройти повний курс навчань персоналу. Завершення цих заходів заплановано на початок 2012 р., а протягом 2011 р. проведено два навчальних курси з експлуатації мобільної радіологічної лабораторії, на базі Їнституту ядерних досліджень для фахівців, які входять до складу екіпажів радіологічної лабораторії, проведено практичні тренування, за результатами яких ДНТЦ ЯРБ підготовлено та надано державному регулюючому органу Фінляндії (STUK) перелік додаткового обладнання, необхідного для ефективної роботи лабораторії. 3 боку STUK планується надання практичної допомоги українським фахівцям в обміні досвідом щодо використання лабораторії в ході підготовки та реалізації заходів забезпечення радіаційної безпеки при проведенні ЄBPO-2012.

Науково-дослідні та аналітичні роботи. Наукові дослідження ДНТЦ ЯРБ у розвиток стратегії державного регулювання ЯРБ протягом звітного періоду мали на меті вивчення та імплементацію передових методологій у практику регулювання, визначення й обгрунтування принципів, критеріїв і цілей безпеки, необхідних для запровадження політики та технічних вимог регулюючого органу.

У 2011 р. ДНТЦ ЯРБ виконувалися 44 науково-дослідні роботи.

Одним з першочергових завдань Плану дій щодо цільового позачергового оцінювання стану безпеки та по- 
дальшого підвищення безпеки енергоблоків АЕС України 3 урахуванням подій на АЕС «Фукусіма-1» $є$ проведення аналізу нормативно-правової бази ЯРБ та розробка пропозицій щодо іiї вдосконалення та підвищення вимог з безпеки для діючих та нових енергоблоків АЕС. 3 цією метою у 2011 р. Держатомрегулюванням України було доручено ДНТЦ ЯРБ виконання низки наукових досліджень, a caмe:

«Комплексний аналіз норм, правил та стандартів з ядерної безпеки з урахуванням уроків аварії на AEC "Фукусіма-1" та підготовка пропозицій щодо внесення змін»;

«Розробка вимог до систем аварійного охолодження та відведення тепла від ядерного реактора до кінцевого поглинача»;

«Перегляд вимог до локалізуючих систем безпеки»;

«Розробка вимог до сейсмостійкого проектування та оцінки сейсмічної безпеки енергоблоків АЕС»;

«Розробка вимог до поводження зі свіжим та відпрацьованим ядерним паливом на АEC».

Станом на кінець 2011 р. завершено першу з перелічених НДР. Визначено основні фактори, недоліки та відмови, сукупність та послідовність яких призвели до виникнення на майданчику АЕС «Фукусіма-1» важкої аварії з довготривалими радіаційними наслідками. Фахівцями ДНТЦ ЯРБ виконано аналіз діючої в Україні нормативної бази з ЯРБ та сформовано попередній перелік документів, що потребують коригувань, визначено напрями перегляду документів з урахуванням аварійних феноменів, що мали місце на АЕС «Фукусіма-1». У 2012 р. планується завершити ще чотири НДР.

Серед знакових подій 2011 р. для ДНТЦ ЯРБ слід відмітити виконання фахівцями підприємства НДР за темою «Розробка нормативної документації щодо забезпечення безпеки підкритичної збірки».

На виконання Указу Президента України від 09.04.10 № 536-11т та Доручення Президента України від 04.06.10 № 1-1/1083 в Національному науковому центрі «Харківський фізико-технічний інститут» (далі - ННЦ ХФТї) провадиться діяльність з будівництва ядерної установки «Джерело нейтронів, засноване на підкритичній збірці, керованій електронним прискорювачем» (далі - підкритична збірка), яку планують запустити в 2014 р. На даний час чинними є вимоги з безпеки підкритичної збірки, що встановлені у нормативних документах колишнього СРСР, але вони потребують перегляду для врахування сучасних міжнародних рекомендацій та науково-технічних даних щодо забезпечення безпеки підкритичних збірок.

Мета виконання цієї НДР - розробка нормативної документації щодо забезпечення безпеки підкритичної збірки, яка відповідає рекомендаціям МАГАТЕ та кращому міжнародному досвіду, а також враховує новітні науково-технічні дані щодо забезпечення безпеки підкритичних збірок.

За результатами роботи фахівцями ДНТЦ ЯРБ:

виконано аналіз міжнародних рекомендацій та нормативних вимог, чинних в Російській Федерації, щодо забезпечення безпеки підкритичної збірки;

підготовлено першу редакцію НПА «Загальні положення безпеки ядерної підкритичної установки»;

проведено професійне та громадське обговорення проекту першої редакції документа;

за результатами обговорення зведено відгуки зацікавлених організацій на проект остаточної редакції документа, що встановлює загальні положення безпеки підкритичної збірки.
Результати роботи будуть використані ННЦ ХФТІ на етапах проектування, будівництва та експлуатації підкритичної збірки.

У 2011 р. фахівцями ДНТЦ ЯРБ завершено виконання НДР «Розробка розрахункових моделей паливних касет реакторів ВВЕР для програми HELIOS $i$ їх валідація з метою впровадження у практику експертних робіт Держатомрегулювання для підвищення якості оцінки безпеки при експлуатації активних зон реакторів ВВЕР».

Основним інструментом з досліджень фізики реакторів ВВЕР, що використовується ДНТЦ ЯРБ, є двогрупова дифузійна програма DYN3D. У попередні роки для підготовки двогрупових дифузійних констант для DYN3D фахівцями ДНТЦ ЯРБ застосовувався спектральний код NESSEL-4, розроблений в Німеччині.

Впровадження в експлуатацію на АЕС України нових типів палива виявило необхідність використання для підготовки нейтронно-фізичних констант (далі - НФК), потрібних для виконання фізичного розрахунку активної зони реактора, сучасного розрахункового коду, що описує реальну геометрію тепловидільних збірок (далі - ТВ3). Для досягнення цієї цілі в ДНТЦ ЯРБ отримано програму HELIOS, що використовується для підготовки НФК різних типів реакторів більш ніж у 15 країнах світу.

В рамках цієї НДР розроблено структуру вихідного файлу програми HELIOS, в якому зберігаються всі результати розрахунків відповідно до переліку розрахунків станів активної зони реактора. Використовуючи методологію найменших квадратів, фахівці ДНТЦ ЯРБ розробили додаткову сервісну програму, яка виконує взаємодію між вихідним файлом HELIOS та вхідним файлом до програми DYN3D. За результатами досліджень для програми DYN3D отримано константи, необхідні для розрахунків нових типів паливних касет, що використовуються на українських AEC; за їх допомогою виконано тестові розрахунки кількох паливних завантажень реакторів ВВЕР-440, 1000.

Робочий інструмент, отриманий за результатами НДР, дозволяє на сучасному рівні оперативно оцінювати безпечність експлуатації паливних завантажень та обгрунтовувати впровадження нових типів палива на українських АЕС, що $є$ важливим під час прийняття регулюючим органом piшення про надання дозволів на експлуатацію активних зон реакторів ВВЕР з точки зору оцінки їх ядерної безпеки.

Аналіз рівня безпеки ЯУ - це комплексна проблема, найважливішою складовою частиною якої є аналіз міцності та ресурсу основних несучих елементів конструкцій корпусу реактора, руйнування яких може призвести до аварій 3 найважчими наслідками. Останнім часом особлива увага приділяється теплогідравлічним аспектам взаємодії матеріалу корпусу реактора з сумішшю теплоносія і борного розчину, який подається в перший контур насосами системи аварійного охолодження зони. На вирішення цього питання були спрямовані дослідження фахівців ДНТЦ ЯРБ, що представлені в НДР за темою «Комплексні теплогідравлічні аналізи для дослідження впливу термошоку».

Оскільки термічні та гідравлічні навантаження, які виникають в разі потрапляння холодної води на метал конструкцій, можуть бути небезпечними з точки зору як циклічної міцності, так і з точки зору крихкого руйнування, великого значення набувають якість та обсяг результатів теплогідравлічних розрахунків. Ці результати в подальшому використовуються як граничні умови в аналізах напружено-деформованого стану і крихкої міцності корпусів реакторів типу ВВЕР. 
Беручи до уваги, що інтегральні комп'ютерні моделі РУ, які використовуються в ДНТЦ ЯРБ для розрахункового коду RELAP5/MOD3.2, дають змогу отримати тільки середньо-змішані значення параметрів із певним розрахунковим обсягом, а інтерес становить саме інформація про локальні значення параметрів теплоносія, борного розчину та їхньої суміші, фахівцями ДНТЦ ЯРБ було досліджено вплив термошоку на корпус реактора. Проведено дослідження стосовно виконання розрахункових аналізів 3 використанням комп'ютерного коду RELAP5/MOD3.2:

здійснено попередній системний аналіз щодо вибору сценаріїв найбільш важливих з точки зору дослідження впливу термошоку;

розроблено спеціалізовану теплогідравлічну модель РУ BВEР-1000 для оцінки впливу термошоку корпусу реактора; виконано розрахункові аналізи представницьких сценаріїв із застосуванням розробленої спеціалізованої моделі PУ ВBEP.

За результатами всього комплексу проведених робіт ДНТЦ ЯРБ розроблено гнучку модель енергоблока ВВЕР-1000 та набір результатів розрахунку процесів із перемішуванням теплоносія. Результати цих досліджень можуть бути корисні під час розроблення галузевих програм продовження ресурсу корпусів реакторів та обладнання енергоблоків, проведення експертизи розрахункових матеріалів та в подальшій дослідницькій діяльності.

У 2011 р. ДНТЦ ЯРБ завершена НДР «Оперативний та технологічний аналіз порушень у роботі АЕС України у 20092010 pp.». Робота за даним напрямом щорічно виконується ДНТЦ ЯРБ, починаючи з 1993 р., і є ключовою для здійснення аналізу досвіду експлуатації АЕС України.

Протягом року проводилися роботи за третім етапом цієї НДР: «Оперативний та технологічний аналіз порушень в роботі АЕС України за 2010 рік».

Аналіз порушень у роботі АЕС України спрямований на запобігання виникненню порушень, підвищення ефективності використання досвіду експлуатації АЕС та підвищення рівня експлуатаційної безпеки, а також на правильність визначення причин порушень та адекватність призначених коригувальних заходів.

У 2010 р. на АЕС України сталося 22 порушення (рис. 1). Середня кількість порушень на один енергоблок найменша на Рівненській AEC (одне порушення на енергоблок), найбільша - на ХАЕС (три порушення на один енергоблок). Встановлено, що тільки одне порушення сталося на енергоблоці з реактором типу ВВЕР-440, інші 21 - на AЕC з реакторами типу ВВЕР-1000.

За результатами поглибленого аналізу порушень у роботі АЕC виявлено недоліки в якості розслідування порушень та складання звітної документації; системі подовження терміну експлуатації обладнання систем безпеки та систем, важливих для безпеки; вхідному контролю на АЕС та (чи) вихідному контролю на заводі-виробнику; достатності в обсягах навчання на повномасштабному тренажері. Держатомрегулюванню України рекомендовано ознайомити ДП НАЕК «Енергоатом» і AЕС з результатами НДР та зобов'язати врахувати в подальшій роботі надані рекомендації.

У другому півріччі 2011 р. розпочато нову НДР, до якої увійдуть дані про аналіз кількості порушень, які сталися на АЕС України протягом 2011-2012 рр.

За дорученням Держатомрегулювання України, ДНТЦ ЯРБ власними силами виконано 45 аналітичних досліджень 3 обгрунтування регулюючих рішень стосовно узгодження планів та заходів щодо впровадження або реалізації

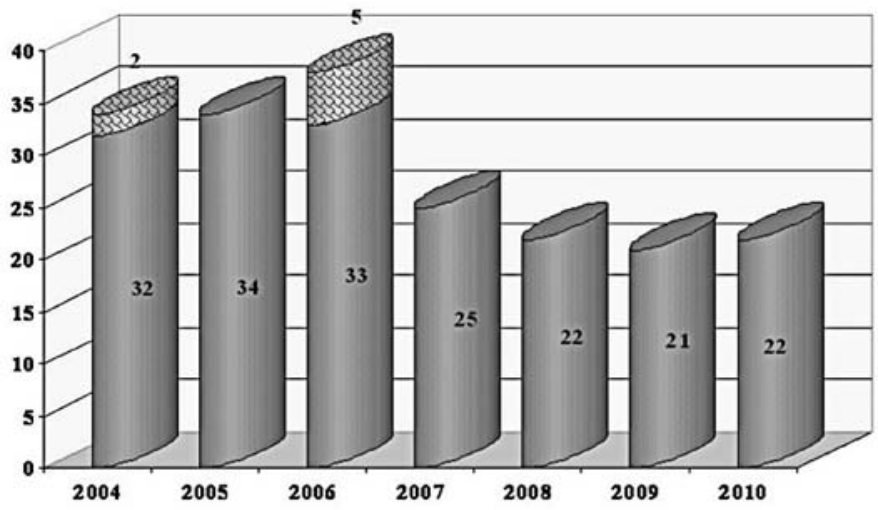

Рис. 1. Кількість порушень у роботі АЕС України в 2004-2010 pp.

заходів із підвищення безпеки енергоблоків АЕС України, державних та галузевих програм.

Для виконання розрахункових аналізів прогнозного характеру в разі аварій на АЕС України, а також аналітичних досліджень аварійних режимів, у ДНТЦ ЯРБ впроваджується система оперативного моніторингу технологічних параметрів енергоблоків АЕС України.

Науково-інформаційна діяльність. ДНТЦ ЯРБ виконує роботи, спрямовані на популяризацію наукових знань та досягнень у сфері використання ядерної енергії, підвищення спроможності підприємства у вирішенні найскладніших питань безпеки, зростання наукового потенціалу та професіоналізму.

На регулярній основі видається спеціалізований журнал «Ядерна та радіаційна безпека». Журнал зареєстровано у Вищій атестаційній комісії України (далі - ВАК України) як фахове наукове видання з технічних наук та включено до нового Переліку наукових фахових видань ВАК України, в яких можуть публікуватися результати дисертаційних робіт на здобуття наукових ступенів доктора та кандидата наук. У базі даних МАГАТЕ з наукових публікацій INIS (International Nuclear Information System) розміщуються анотації статей, опублікованих у журналі. Їнформація про основні завдання журналу, постійні рубрики, правила подання статей авторами, склад редколегії, зміст чергових випусків журналу розміщується на сайті ДНТЦ ЯРБ.

У чотирьох номерах журналу «Ядерна та радіаційна безпека» за 2011 р. опубліковано 26 статей науковців ДНТЦ ЯРБ, 14 статей - в інших вітчизняних та зарубіжних друкованих виданнях: у збірниках наукових статей Українського ядерного товариства; у виданнях Харківського фізико-технічного інституту НАН України; науково-технічному збірнику Всеросійського науково-дослідного інституту експериментальної фізики «Вопросы атомной науки и техники», журналах «Искателям приключений - ВОЛОНТЁР» та «Проблеми безпеки атомних електростанцій і Чорнобиля» тощо.

Завдяки публікаціям у журналі «Ядерна та радіаційна безпека» цього року оприлюднено результати робіт 22 зовнішніх організацій.

У серії «Безпека атомних станцій» вийшла книга «Системы управления и защиты ядерных реакторов».

У 2011 р. розроблено веб-сайт журналу «Ядерна та радіаційна безпека» $з$ метою його популяризації за кордоном та інтеграції до світової наукової спільноти, входження до найбільшої в світі бібліографічної та реферативної бази даних Scopus, яка служить інструментом для відстеження цитованості статей, опублікованих у наукових виданнях. 
У вересні 2011 р. за результатами участі у Х Міжнародному виставковому форумі «Технології захисту-2011» журнал «Ядерна та радіаційна безпека» відзначено дипломом.

У 2011 р. фахівці ДНТЦ ЯРБ брали участь у понад 40 заходах, що проводилися МАГАТЕ, науковими організаціями та організаціями технічної підтримки регуляторів США, Німеччини, Франції, Бельгії, Фінляндії, І̇талії, Швеції, Чехії, Угорщини, Словенії, Білорусі, Росії, які були спрямовані на подальший розвиток співпраці, обговорення результатів спільної діяльності, а також на обмін досвідом щодо забезпечення ЯРБ.

У жовтні 2011 р. ДНТЦ ЯРБ брав участь в організації проведення дев'ятої міжнародної науково-практичної конференції з проблем атомної енергетики «Безпека, ефективність, ресурс ядерних енергетичних установок» у м. Севастополі, яка була присвячена обговоренню сучасних проблем атомної енергетики, пов'язаних із забезпеченням надійності, безпеки й ефективності експлуатації АЕС, необхідністю управління ресурсом устаткування енергоблоків і продовження строків їх експлуатації тощо.

3 нагоди святкування у березні 2012 р. 20-ліття створення ДНТЦ ЯРБ, у 2011 р. підприємством розпочато підготовку до проведення Міжнародної науково-практичної конференції за участю представників органів державного регулювання ЯРБ та провідних спеціалістів атомної енергетичної галузі.

Підготовлено до випуску книгу, присвячену 20-й річниці створення ДНТЦ ЯРБ, що відображує історію підприємства від часів створення, етапи становлення та розвитку, а також результати роботи структурних підрозділів ДНТЦ ЯРБ.

\section{Висновки}

Науково-технічна діяльність ДНТЦ ЯРБ відповідно до Статуту підприємства здійснюється за завданням Держатомрегулювання України та спрямована на науковотехнічну підтримку регулюючого органу. У звітному році ДНТЦ ЯРБ вжито низку заходів, спрямованих на розвиток системи науково-технічної підтримки державного регулювання безпеки:

науковими підрозділами підприємства взято участь у реалізації невідкладних заходів з удосконалення нормативно-правової бази України відповідно до Плану дій щодо виконання цільової позачергової оцінки стану безпеки та подальшого підвищення безпеки енергоблоків АЕС України з урахуванням подій на АЕС «Фукусіма-1»;
ДНТЦ ЯРБ включено до співорганізаторів щорічного Форуму EUROSAFE;

проведено низку двосторонніх переговорів і презентаційних заходів щодо розвитку співпраці як з провідними вітчизняними науковими установами, так і з зарубіжними партнерами, що сприяє впровадженню та використанню в повсякденній практиці підприємства найкращих сучасних підходів, технологій і методик у сфері регулювання ядерної та радіаційної безпеки;

фахівцями ДНТЦ ЯРБ проведено низку навчань представників органів ядерного регулювання зарубіжних країн.

Підсумовуючи результати роботи підприємства за час його існування, можна констатувати: ДНТЦ ЯРБ накопичено достатній науково-технічний потенціал, що дозволяє успішно вирішувати комплекс питань надання науковотехнічної підтримки Держатомрегулюванню України та надалі ефективно й успішно реалізовувати плани розвитку ядерної галузі.

Пріоритетні завдання ДНТЦ ЯРБ протягом наступних років будуть спрямовані на розширення потенціалу науково-технічної діяльності завдяки розвитку додаткових експертних можливостей та підсиленню оснащеності.

\section{Список використаної літератури}

1. Носовский A. B. Научные аспекты регулирования ядерной и радиационной безопасности // Ядерні та радіаційні технологіiі. - 2007. - T. 7, № 1-2. - С. 38-45.

2. Постанова Колегії Держатомрегулювання від 19 травня 2011 р. «Шодо Плану дій з виконання цільової позачергової перевірки та подальшого підвищення безпеки АЕС України з урахуванням подій на Фукусіма-1 («stress-test»)».

3. Річний звіт про основну діяльність ДНТЦ ЯРБ у 2011 році.

4. Постанова Колегії Держатомрегулювання від 3 листопада 2011 р. «Щодо виконання ДСП “Чорнобильська АЕС” цільової позачергової оцінки стану безпеки енергоблоків $1 \div 3$ та СВЯП-1 з урахуванням подій на АЕС “Фукусіма-1"》.

5. Постанова Колегії Держатомрегулювання від 24-25 листопада 2011 р. «Про результати виконання цільової позачергової оцінки стану безпеки діючих енергоблоків АЕС та ССВЯП ЗАЕС з урахуванням подій на АЕС “Фукусіма-Даічі” . 